Article

\title{
Second-Chance Alternatives and Maintained Inequality in Access to Higher Education in Israel
}

\author{
Eyal Bar-Haim ${ }^{1, *}$ and Carmel Blank ${ }^{2,3}$ \\ ${ }^{1}$ PEARL Institute for Research on Socio-Economic Inequality, University of Luxembourg, 4366 Esch-sur-Alzette, \\ Luxembourg; E-Mail: eyal.bar-haim@uni.lu \\ 2 Department of Sociology and Anthropology, Tel Aviv University, 6997801 Tel Aviv, Israel; E-Mail: blankcar@post.tau.ac.il \\ ${ }^{3}$ School of Applied Social Sciences, Durham University, Durham, DH1 3HN, UK \\ * Corresponding author
}

Submitted: 12 June 2018 | Accepted: 2 September 2018 | Published: 10 January 2019

\begin{abstract}
Students are expected to obtain a matriculation diploma during their high school years. Throughout the world, it is considered as a precondition to gaining access to higher education. However, those who failed to meet this criterion can employ, in some cases, "second-chance" alternatives-either to obtain a diploma at an older age, or to enter specific academic programs that do not require one. The literature on second-chance alternatives tends to concentrate on these programs' evaluation. It rarely addresses the overall effect of these programs on inequality of educational opportunities (IEO). The current study focuses on Israelis who failed to gain a matriculation diploma at their high school graduation and contemplate on the effects that ethnic differences between them play on their chances to enter higher education. Based on a new Panel survey (2012-2016), we found that Israelis from affluent ethnic backgrounds were able to increase their chances to access higher education using "second-chance alternatives". Those from minority groups, most notably Arabs, were less likely to benefit from these alternatives. While originally aimed at improving higher education enrolment for people from disadvantaged backgrounds, these "second-chance alternatives" resulted in an increase of ethnic-based IEO. Considering the lower rates of Israelis who utilise them, we deduct that these programs "failed" to accomplish their original purpose. However, we argue that they merit further research since their understanding can benefit researchers and policy makers.
\end{abstract}

\section{Keywords}

education; enrolment; inequality; Israel; second-chance; Higher education

\section{Issue}

This article is part of the issue "Inequalities in Access to Higher Education: Methodological and Theoretical Issues", edited by Gaële Goastellec (University of Lausanne, Switzerland) and Jussi Välimaa (University of Jyväskylä, Finland).

(C) 2019 by the authors; licensee Cogitatio (Lisbon, Portugal). This article is licensed under a Creative Commons Attribution 4.0 International License (CC BY).

\section{Introduction: Second-Chance Alternatives as a Form of Educational Expansion}

Higher education is considered a scarce commodity. Apart from the very basic educational levels, which are accessible to almost everyone, climbing up the educational ladder is a competition with winners and potential losers. Usually, competition for a seat at the higher levels of the educational system requires a universal test or other method of screening. Those who are found as qualified can proceed to the next level, while others leave the system completely or settle for a less prestigious path. However, since the ability of students to pass the selection process is largely dependent on their social background (Au, 2014; Feniger, 2018; Triventi, Panichella, Ballarino, Barone, \& Bernardi, 2016) and it only loosely predicts their actual success in the next educational level (Beller, 2001), the fairness of these procedures is under scrutiny (Arbel, Bar-El, \& Tobol, 2017).

Therefore, "second-chance alternatives" which allow students who failed the screening process to enter the next level of education are important. When these pro- 
grams are truly accessible to everyone (Inbar \& Sever, 1989; Savelsberg, Pignata, \& Weckert, 2017), they are assumed to reduce the level of inequality in opportunities, since people from lower backgrounds can use them to enter the educational level they were previously denied. Moreover, they undermine the importance of universal tests or other selection methods, and present a convincing argument for their elimination: if a student who is not qualified by the official assessment is able to succeed, what is the purpose of the screening process?

This study presents a different approach. We see the existence of second-chance paths as a form of educational expansion. The possibility to continue to the next educational level without passing the screenings enables more students to expand their educational opportunities (Buchholz \& Schier, 2015; Schudde \& Goldrick-Rab, 2015). This is especially true when the second-chance opportunity is universal. If the second-chance option is accessible to anyone failing the traditional education system, it is the equivalent of reducing the relative cost of education for individuals, similar to the effective cost reduction provided by educational expansion (Raftery \& Hout, 1993). In these circumstances, students view the opportunity to acquire education as less costly, since they do not need to spend time repeating the previous level of education (Raftery \& Hout, 1993).

We would expect that second-chance programs would increase inequality of educational opportunities, in line with Raftery and Hout's (1993) Maximally Maintained Inequality (MMI) hypothesis. According to this hypothesis, students from affluent background are more able to exploit new educational opportunities-like educational expansion or second-chance programs-and therefore are more likely to take advantage of these opportunities (Raffe, 1979). Hence, the proportion of students from advantaged background will increase at a higher rate than that of students from lower background and the inequality of educational opportunity (IEO) would rise. Studies of both educational expansion (Bar-Haim \& Shavit, 2013) and second-chance programs (Ayalon, 1990) empirically support this hypothesis.

When the second-chance program is targeted toward a specific group, however, the situation is quite different. In that case, students outside the targeted group cannot exploit the opportunity and therefore, the program is expected to reduce at least nominal IEO. At the same time, there is a risk that the new program will mark its members as a distinguished group in a way that would affect their future educational attainment (Blank, 2008). We parallel this mark-up to the Effectively Maintained Inequality (EMI) hypothesis (Ayalon \& Shavit, 2004; Lucas, 2001, 2009; Marks, 2013). This hypothesis emphasizes the qualitative differences between old and new educational opportunities and claims that while the nominal IEO would decrease due to the expansion, the IEO in entering the next level would increase or at least remain stable through differences in the quality of educational institutions, fields of study etc. While there is much less em- pirical evidence on the effect of such targeted programs to support this claim (Gale \& McNnamee, 1995), some results (Shavit, Ayalon, \& Kurlaender, 2002) demonstrate that when a second-chance program was able to reduce inequality in the specific level, the beneficiaries of it suffered from a disadvantage in the next educational level, thus the IEO increased in the following levels.

Based on these insights, we examine second-chance paths for accessing academic education in Israel and its effect on ethnicity-based IEO. We do so by testing who are the beneficiaries from these opportunities using the Israeli household panel survey (Central Bureau of Statistics, 2013, 2014, 2016, 2017a, 2017b). The next section presents the ethnic inequality in Israeli society in general and in the education system in particular. This is followed by a description of the second-chance alternatives in Israel, which are aimed mainly at disadvantaged groups, but may nevertheless benefit the stronger.

\section{The Israeli Context: Ethnically Stratified and Educationally Unequal}

\subsection{The Israeli Education System}

As in most developed countries, the Israeli education system consists of four stages: elementary, middle, secondary and higher. Students in secondary school are assigned to academic tracks, which prepare them for higher studies, and to vocational tracks, which combines academic and vocational training. Vocational tracks are usually attended by scholastically weaker students who have not done well in middle school (Blank, Shavit, \& Yaish, 2016), but students on all tracks can sit for the matriculation exams.

From elementary to high school, Israel's education system is divided into several sectors, reflecting the ethnic and social diversity in Israel. Arabs and Jews are highly segregated in the school system (Shavit, 1990), as most Arab students attend Arabic-speaking schools and virtually all Jews attend Hebrew-speaking schools. The Hebrew-speaking school system consists of three main sectors: non-religious state schools, attended by about $55 \%$ of all Jewish students; religious state schools, serving about $20 \%$ of Jewish students and ultra-orthodox schools, catering to approximately $25 \%$ of Jewish students (Blank \& Shavit, 2016; Blass \& Shavit, 2017; Chachashvili-Bolotin \& Lissitsa, 2016). Most Arabs attend Arab state schools (there are no state religious Arab schools), but a sizable minority of Arab students, Christian and Muslim, attend private parochial Christian schools founded by various Christian denominations. These are generally regarded as being of better quality than the state schools (Al-Haj, 2012; Okun \& Friedlander, 2005).

While the transition from elementary to middle school is mandatory, much like that from middle to high school, admission to most higher education institutions-state universities, colleges or private colleges-requires sufficient score in a psychometric test 
(Helms, 2015) and matriculation diploma (Bagrut). The diploma is granted to those passing the final exams in several mandatory subjects and additional elective subjects at advanced level. The grades further affect the odds of being admitted to selective university departments. In recent years, over $70 \%$ of birth cohorts sat at least one matriculation exam (Central Bureau of Statistics, 2017b). However, only about $48 \%$ passed all necessary exams and were eligible for the matriculation diploma.

Since absence of matriculation diploma can deny access to higher education, there ley the need for secondchance opportunities.

\subsection{Inequality of Educational Opportunities and Ethnic Stratification in Israel}

Inequality of educational opportunities in Israel has been politically perceived in the broader context of ethnic and class stratification. Three major distinct ethnic groups account for most of the population: Jews of European and American origin (Ashkenazy Jews); Jews of African and Asian origin (Mizrahi Jews); and Arabs. This diversity greatly affects stratification in Israel. Israeli Arabs are characterized as being of lower socio-economic status than Jews in every aspect of stratification, including educational and economic outcomes (Cohen, Haberfeld, \& Kristal, 2007; Lewin-Epstein \& Semyonov, 1993; Shavit, 1984). Among Jews, those of European and American origin are usually ranked higher on the stratification ladder, although their advantage has been decreasing over generations (Bar-Haim \& Semyonov, 2015). Studies of ethnicity and educational achievements consistently found that Ashkenazy Jews are more likely to obtain higher educational certifications than Mizrahi Jews and Arabs (Bar-Haim \& Semyonov, 2015; Bar-Haim, Yaish, \& Shavit, 2008; Friedlander, Okun, \& Goldscheider, 2016).

\subsection{Second-Chance Paths in Israel and IEO}

Shavit et al. (2002) name two second-chance paths that were available during the 1990s in Israel. The first is university preparatory programs (Mechinot). These are oneyear studying programs, offered at universities, without the need for matriculation diploma. Students who succeed in these programs are eligible to enter academic institutions in the field of study relevant to the courses they learned at the program. A Reform held in 2011 (The State Comptroller, 2016), determined that credentials given by preparatory programs can replace the matriculation diploma in admission to any academic institution. However, the reform was never fully implemented and in 2013 , only $35 \%$ of the students in preparatory programs were given such a credential. Among the rest, $55 \%$ were tested again in the national exams required for state issued matriculation diploma and $10 \%$ studied for credentials acknowledged only by specific institutes. In addition, since 2011 the preparatory programs have been targeted mainly toward people from lower back- ground, with differential admission cost and unique separate programs for ultra-orthodox Jews, Arabs and new immigrants. Thus, such programs can be expected to benefit primarily disadvantaged students. However, as Shafir and Peled (1998) describe, the mandatory military service in Israel serves as justification for discrimination of Arab citizens who are exempt from it. This is true also for some preparatory schools where students who served in the army are eligible for scholarships and reduced fees. While Mizrahi Jews can benefit from this assistance, it can hinder the Jewish-Arabic equality potential of such programs.

Another route described by Shavit et al. (2002) is the so-called "external" examination, as students sit for matriculation exams after the completion of high school. This is the preferred path for students who took the matriculation exams during high school but failed to make the necessary requirements to be eligible for diploma (either by failing the tests or taking only part of the required exams). This option is universal and not targeted toward a specific group, with only minimal fee. However, there are private and public preparatory schools for tutoring students before the exams, with considerable admission fees (Addi-Raccah \& Dana, 2015; Zilkha, 2017) that can enhance the success of more affluent students. During the previous decade, a third second-chance path emerged in the form of acceptance to higher education institutions based solely on the psychometric tests. This option is available in several colleges and specific, less prestigious fields of study in universities. It does not target specific group, but due to the limited available fields of study and the demand for relatively high psychometric score, this path is relevant only for a small fraction of students, mainly from advantaged groups who can take preparatory courses before the psychometric test (Davidovitch \& Soen, 2015). In addition, students from lower background are rarely aware of their options to enter academics institutions without the need of a matriculation diploma (Ayalon, 1990), since these options are usually suggested-by each academic institution-only to those already applied and are not widely publicized. In that sense, only people with suitable social and cultural capital are aware of these options.

Overall, the above-mentioned mechanisms do not suggest a clear beneficiary for second-chance programs in Israel. While targeted programs might be beneficial for the weakest groups, the accessibility of the opportunities might provide an advantage for stronger groups. Hence, two contradicting hypotheses can be inferred:

H1: The second-chance paths make academic education more accessible for scholastically-weak students from stronger background (Ashkenazi Jews) thus increasing IEO in academic education.

$\mathrm{H} 2$ : The second-chance paths targeted toward the weaker ethnic groups made academic education more accessible for students coming from a weaker back- 
ground (Arabs and Mizrahi Jews). Therefore, they decrease IEO in academic education.

\section{Analytical Strategy: Using New Israeli Panel Data to Estimate the Chance of Entering an Academic Institution via Second-Chance Program}

\subsection{Data: Israel Longitudinal Survey}

In this study, we employ a relatively new data set provided by the Israeli Central Bureau of Statistics. The data set, known as Israel Longitudinal Survey is based on annual panel consisting of four waves (2012-2016) of more than 4,000 Israeli households in a representative sample of the entire population of long-term residents of Israel. The number of individuals for whom there is at least one observation is about 20,000. However, only $70 \%$ of the respondents were interviewed more than once and information for all four waves was only available for 4,182 respondents.

We further limited the sample to respondents aged 19 to 35 for Arabs and 21 to 37 for Jews to account only for respondents who completed (or dropped out of) secondary education and to avoid the problem of selection through military service. ${ }^{1}$

The panel lacks any information on parental background and has no identifier for specific ethnicity of firstgeneration immigrants (former FSU and immigrants from Ethiopia). Therefore, we restricted the sample to include only Israeli born individuals. The number of respondents in the final restricted sample is 2,960 .

\subsection{Research Variables: Monitoring Educational and Ethnic Characteristics}

The dependent variable used in the study relates to the studying status, i.e., whether the respondent study during the panel or previously studied in an academic institution. We consider only respondents who studied at an Israeli institution (for which matriculation diploma is usually required).

The first independent variable-Matriculationindicates whether the respondent obtained a matriculation diploma after the expected end of high school (age 18) at the start of the panel period (in 2012).

The classification of respondents' ethnicity is based on parental country of birth and self-identification ethnicity (in the case of Arabs). We differentiate between four of the most common ethnic categories in Israel, using dummy variables: Ashkenazi (for respondents who came, or their father came, from Europe and America), third generation Jews (respondents that their parents are Israeli born), Mizrahi Jews (Asia and Africa) and
Arabs. For mixed ethnicity ( $12 \%$ of the overall sample, $11 \%$ in the restricted sample), we used a dominance approach, i.e., we gave the respondent the highest prestige ethnicity of the parents. Ashkenazi Jews are the reference category. ${ }^{2}$

We control for ultra-orthodox ("Haredi") Jews, based on respondents' own declarations. This group usually attends separated schools, without taking any matriculation exams. As a result, almost no members of the group have a matriculation diploma. However, some ultraorthodox Jews in Israel enter higher education, exploiting targeted programs. Ultra-orthodox Jews are mainly Ashkenazi and third generation Israeli born $(42.4 \%$ and $47.2 \%$ respectively) and therefore it is important to control this attribute.

In addition, controls are placed for gender (men $=0)$ and age (based in year of birth).

\subsection{Statistical Methods}

Logistic regression is used to estimate the effect of ethnicity on the chances of entering an academic institution through a second-chance program. The predictor is studying now or in the past at an academic institution. The independent variables are having matriculation diploma at the start of the panel, ethnicity, ultraorthodox, gender and age. We also estimate the interaction effect between ethnicity and matriculation diploma. Equation 1 demonstrates the model.

Equation 1:

$$
\begin{aligned}
\log \left(\frac{p_{y}}{1-p_{y}}\right)=a & +b_{1} \text { Matriculation }+b_{2} \text { Ethnicity } \\
& +b_{3} \text { Matriculation } \times \text { Ethnicity } \\
& +b_{4} \text { UltraOrthodox }+b_{5} \text { Female } \\
& +b_{6} \text { Age }+e
\end{aligned}
$$

\section{Results: Do Strong Ethnic Groups Have an Advantage in Exploiting Second-Chance Programs in Israel's Higher Education System?}

The analysis is divided into two sections. The first is descriptive and depicts rates of students enrolled in academic institutions by 2016, who did and did not have matriculation diploma at the end of high school. The second comprise a logistic model employed to estimate inequality in the chances of accessing higher education, controlling for the status of matriculation diploma at the end of high school.

As seen in Table 1, less than 3\% failed to gain a matriculation diploma at their high school graduation in 2012, yet still enrolled into higher education through second-

\footnotetext{
${ }^{1}$ As Arabs are exempt from mandatory military service, they enroll in higher education shortly after their high school graduation whereas Jews serve 2-3 years in the army and only then can turn to higher education. In an unreported analysis, we include the same age range for both Arabs and Jews. The results of the logistic regression were similar, but the percentage of third generation Israeli Jews who enroll to academic institution was considerably smaller, due to their later entry.

2 In an unreported analysis, we employ the model with a separate category for mixed ethnicity. The results were very similar to the analysis presented here, with the mixed category preforming very similar to the third generation Israeli born Jews.
} 
Table 1. Distribution (\%) of the studying status by 2016 of respondents who did and did not had Matriculation diploma at 2012.

\begin{tabular}{lcc}
\hline & \multicolumn{2}{c}{ Had Matriculation diploma in 2012} \\
\hline Study in academic institution by 2016 & No & Yes \\
No & $97.68 \%$ & $57.09 \%$ \\
Yes & $2.32 \%$ & $42.91 \%$ \\
Total & $100 \%$ & $100 \%$ \\
\hline
\end{tabular}

Notes: $\mathrm{N}=2,960$; weighted $=507,606$.

chance alternatives. Thus, their ability to affect IEO in Israel is rather low, and this will be discussed at the final section of this article. This is in line with previous findings, for example, from the Israeli Social Survey (Central Bureau of Statistics, 2017b) where among a similar age group, $2.7 \%$ of the respondents without a matriculation, enrolled in higher education.

Figure 1 presents the overall access to higher education, compared to access to higher education without a matriculation diploma at high school's graduation within each of the ethnic groups. In line with previous findings (Bar-Haim \& Semyonov, 2015; Cohen et al., 2007), ethnic differences in academic attainment exist regardless of any second-chance possibility, and they are also present when considering these second-chance alternatives. However, the latter differences are much more prominent. For example, while holding matriculation diploma at high-school graduation, the chances of Ashkenazi Jews to attend academic institution are almost three times higher than those of Arab, and $20 \%$ higher than those of Mizrahi Jews. Among second-chance users, it is closer to four times and two times, respectively.

The results from our logistic model are presented in Table 2. We utilise this model to estimate inequality in the chances to enrol in higher education, given the absence of a matriculation diploma at high school's graduation. In line with previous studies and like other countries (Bar-Haim, Chauvel, Gornick, \& Hartung, 2018; Stier \&
Herzberg-Druker, 2017; Van Hek, Kraaykamp, \& Wolbers, 2016), women are more likely to attain academic education than men. In addition, the absence of a matriculation diploma markedly restricts access to higher education (-2.631).

Among those who graduated from secondary education holding a matriculation diploma, there are, as expected, striking differences between Jews and Arab; the chances of Arabs to enter academic education are significantly lower than those of Ashkenazi Jews (-1.341). The chances of Mizrahi Jews and third generation Israeli Jews are also significantly lower compared to those of Ashkenazi Jews, though much higher than the Arabs' chances. These findings are in line with previous studies of academic attainment in Israel; It was illustrated that while Arabs still suffer from disadvantages in educational attainment, Mizrahi Jews have narrowed the educational gap during the last decade (Feniger, Mcdossi, \& Ayalon, 2014). Unsurprisingly, ultra-orthodox Jews are less likely to enter academic education due to their preference to study in religious post-secondary educational systems (Yeshiv'a).

Without a matriculation diploma, the chances of Mizrahi Jews, third generation Israeli Jews and Arabs to enrol in higher education decrease significantly, as seen in the interactions' coefficients, the chances of all three groups to enjoy an alternate path to academic education are lower than the chances of Ashkenazi Jews who gradu-

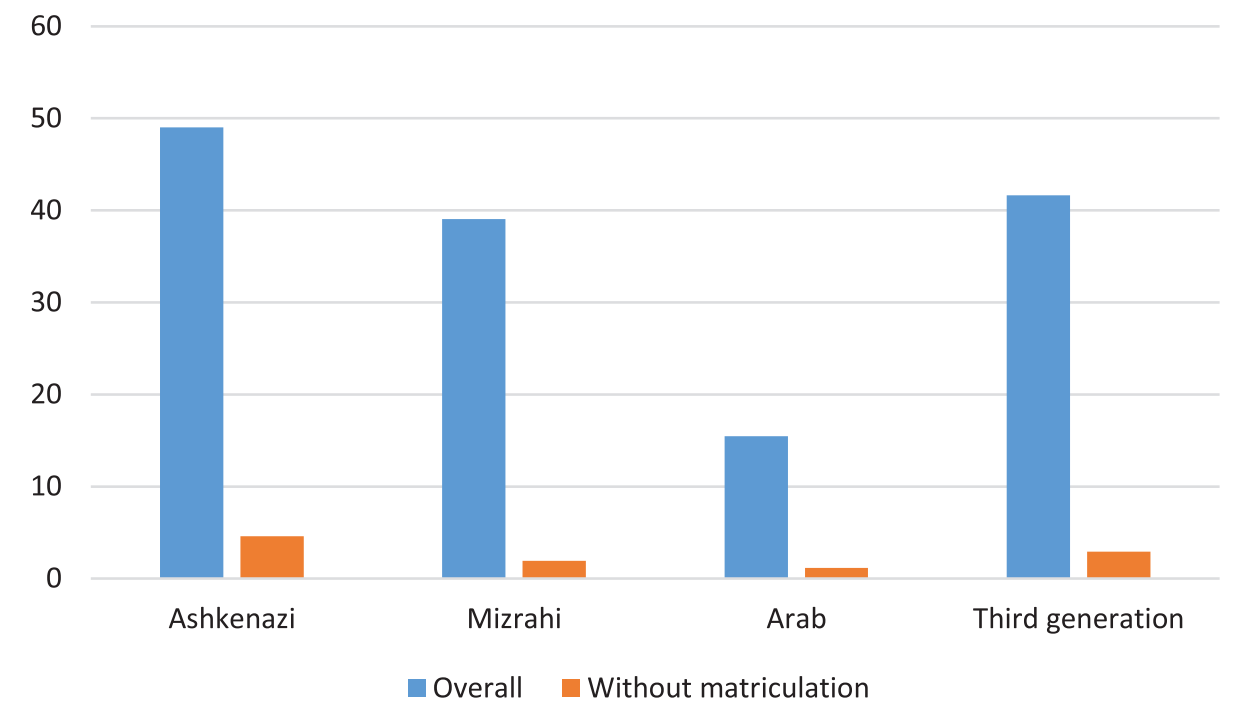

Figure 1. Academic enrolment by ethnic group, overall and without a matriculation diploma at high school's graduation. 
Table 2. Fixed-effects logistic regression for attainment of academic education.

\begin{tabular}{|c|c|c|}
\hline Variable & Coefficients & Marginal effects \\
\hline Absence of matriculation & $\begin{array}{l}-2.631^{* *} \\
(0.012)\end{array}$ & $\begin{array}{c}0.040 \\
(0.001)\end{array}$ \\
\hline \multicolumn{3}{|l|}{ Ethnicity } \\
\hline Ashkenazi & - & $\begin{array}{c}0.585 \\
(0.001)\end{array}$ \\
\hline 3rd generation Israeli Jew & $\begin{array}{c}-.107^{* *} \\
(0.005)\end{array}$ & $\begin{array}{c}0.560 \\
(0.001)\end{array}$ \\
\hline Mizrahi & $\begin{array}{c}-.246 * * \\
(0.008)\end{array}$ & $\begin{array}{c}0.527 \\
(0.001)\end{array}$ \\
\hline Arab & $\begin{array}{c}-1.341^{* *} \\
(0.007)\end{array}$ & $\begin{array}{c}0.284 \\
(0.001)\end{array}$ \\
\hline Ultra-orthodox & $\begin{array}{c}-1.341 * * \\
(0.013)\end{array}$ & - \\
\hline Female & $\begin{array}{c}0.297 * * \\
(0.003)\end{array}$ & - \\
\hline Age & $\begin{array}{c}-.080 * * \\
(0.004)\end{array}$ & - \\
\hline \multicolumn{3}{|c|}{$\begin{array}{l}\text { Interaction with absence of matriculation } \\
\text { Ashkenazi }\end{array}$} \\
\hline & - & $\begin{array}{c}0.052 \\
(0.001)\end{array}$ \\
\hline 3rd generation Israeli Jew & $\begin{array}{c}-.261 * * \\
(0.022)\end{array}$ & $\begin{array}{c}0.017 \\
(0.001)\end{array}$ \\
\hline Mizrahi & $\begin{array}{c}-.885^{* *} \\
(0.042)\end{array}$ & $\begin{array}{c}0.010 \\
(0.001)\end{array}$ \\
\hline Arab & $\begin{array}{c}-.302 * * \\
(0.029)\end{array}$ & $\begin{array}{c}0.036 \\
(0.001)\end{array}$ \\
\hline Intercept & $\begin{array}{c}-2.491 * * \\
(0.012)\end{array}$ & - \\
\hline Pseudo $\mathrm{R}^{2}$ & 0.263 & \\
\hline $\mathrm{N}$ (unweighted) & 2,408 & \\
\hline
\end{tabular}

Note: ${ }^{*}-p<0.01$.

ated high school without matriculation diploma. Mizrahi Jews are particularly disadvantaged as their chances to enrol in academic education are smaller than that of Arabs.

\section{5. "Failed" Expansion and Increased Ethnic IEO}

The study of second-chance alternatives in education predates the literature on educational expansion and inequality of educational opportunities but shares a great deal in common with it. Both fields suggest that policies for reducing inequalities end up maintaining it and often even increase it. This article articulates the resemblance between the two fields and suggests a new way to interpret the implications of second-chance policies considering educational expansion hypothesis, mainly the $\mathrm{MMI}$ and EMI theories.

Our analysis estimated the chances of students to access higher education with and without a matriculation diploma at high school's graduation (i.e., the mainstream path to be eligible for attending academic institutions in Israel). Hence, respondents without the diploma who enter academic education are the ones who exploited second-chance alternative.

We found considerable ethnic differences: without a matriculation diploma at high school's graduation, Mizrahi Jews, third generation Israeli Jews and Arabs were less likely than Ashkenazi Jews to access academic education. While not the most disadvantaged group, Mizrahi Jews suffered the most from not having a matriculation diploma. This suggests that especially for Mizrahi Jews, the second-chance alternatives are a source for increasing IEO. In that sense, the fact that less than 3\% of the students exploit the second-chance alternatives may be part of the explanation for lack of IEO effect on Mizrahi Jews, found in Feniger et al. (2014).

Some of the second-chance alternatives were adjusted to better fit disadvantaged populations; several preparatory programs were given in Arabic and others targeted Jewish students from lower socioeconomic status background, as a combination of means-tested benefit programs combined with military service requirement. 
However, on average, second-chance alternatives were mainly exploited by Ashkenazi Jews. Thus, the programs increased the level of IEO, at least from an ethnic point of view. While there is a strong correlation in Israel between ethnicity and class and Ashkenazi Jews are at the top of economic distributions (Bar-Haim \& Semyonov, 2015), it is still possible that due to variation in economic background of the respondents the results would have differed with regards to parental background based IEO. If we consider second-chance alternatives as a form of educational expansion, or as a means to reducing costs in academic education, then the MMI hypothesis apply to this context. Students from stronger backgrounds were better equipped to exploit the second-chance opportunities than students from weaker backgrounds. Hence, programs that were aimed at reducing inequality were in fact maintaining it, helping weaker students (in our case, academically weak) from stronger backgrounds instead of the other way around. In that sense our findings stand in line with previous studies of second-chance alternatives that found similar results (Ayalon, 1990; Gale \& McNnamee, 1995) and provide a wider theoretical framework that helps us understand these findings.

As mentioned before, less than $3 \%$ of the sample used those opportunities. Since only around a half of the birth cohort obtained a matriculation diploma at high school's graduation (Friedlander et al., 2016), this is not a result of a lack of candidates for second-chance alternatives in Israel. Understanding the reasons to the poor use of these alternatives is beyond the scope of this article. While it means that their overall effect on IEO in Israel is rather low, it also demonstrates that equalizing policies do not fulfil their goal, gaining further support to researches who had similar conclusions.

The relatively small percentage of people who actually utilise second-chance alternatives might serve as a good cause to dismiss the entire notion of alternative paths to access academic education as a way of educational expansion. However, we argue that these programs merit further research since their understanding can benefit researchers and policy makers.

First, the availability of second-chance alternatives for students without a matriculation diploma makes it a unique opportunity to explore expansion in a situation in which the majority of the potential students did not exploit it. Most studies of educational expansion based their measurement of expansion on the increase in participation in higher education (Bar-Haim \& Shavit, 2013; Lucas, 2009; Marks, 2013). Therefore, the measured expansion did not consider the potential students, who were eligible to exploit alternatives to gain a matriculation diploma but did not do so. The current case is a form of such "failed" expansion since we believe that programs in which so many resources have been invested were designed to increase higher education participation of a lot more individuals without a matriculation diploma (The State Comptroller, 2016). The fact that only a small fraction of them actually exploit it does not mean that we cannot study its potential and actual effect on IEO as the programs remain active today and would probably expanded in the future.

As Ayalon, Shapira and Shavit (1992) claim, the availability of second-chance alternatives poses a challenge for mainstream paths. If a second-chance alternative can compensate for twelve years of disadvantage in the mainstream school system and prepare failed students for academic education in a relatively short time, it undermines the entire role of the mainstream system. The fact that a few individuals use it might be, therefore, the result of the strong tendency toward this mainstream system, in which people believe they cannot succeed in higher education without a matriculation diploma. In that sense, second-chance alternatives assist mainly people from higher backgrounds, who are in better position to undermine the mainstream system to begin with. Therefore, the small amount of people from disadvantaged ethnic backgrounds who exploit it might due to strong ethnic discrimination tendency in the education system in Israel. Students from disadvantaged ethnic backgrounds, who failed at high school in much higher rates than students from advantaged groups, also do not believe they are eligible for academic education and would not even try second-chance alternative. As such, it is important even if it affects only a small fraction of the targeted population.

The few individuals who exploit the second-chance alternatives might also be the reason for its increased IEO. The vast majority of people without a matriculation diploma are Arabs or Mizrahi Jews. These groups are less likely to exploit second-chance alternatives. Increasing the accessibility of the programs to these specific groups, can increase their overall effect and may reverse their contribution to IEO.

In terms of social policy, this study raises a question regarding the importance of second-chance alternatives to IEO, in a situation in which they are available, though scarcely used. In these circumstances, the second-chance alternatives, and especially the targeted programs, should be considered a failure. However, more targeted programs and a reaching out policy toward disadvantaged ethnic groups might change the situation and decrease IEO. Our findings can also encourage a re-thinking by policy makers who highly regard these programs as a tool for reducing inequality (The State Comptroller, 2016).

Further investigation of second-chance alternatives should include more details regarding social background. The current available data is not suitable for such a study, maybe because this is the first longitudinal study in Israel and the questionnaire is very concise. With better data, it would be possible to consider not only ethnic background but also parental education and class, which stand at the core of much of the studies presented here. A richer database would also enable a more thorough analysis of the different patterns in which each group exploit second-chance alternatives. Details on the spe- 
cific program used by individuals will allow us to test, for example, whether Arabs do use their targeted programs or if the Arab-Jewish differences in participation are higher in institutions that have military-service based financial aid. In this sense, the current article presents a new angle on an old issue, some "food for thought" for future studies.

\section{Acknowledgements}

The research conducted with the support of the National Research Fund, Luxembourg, in the frame of the Pearl chair project FNR/P11/05 and the frame of the NORFACE-DIAL project "The impact of childhood circumstances over the life-course, IMCHILD", project number INTER/NORFACE/16/11333934. We would like to thank Devora Birgeir for her helpful comments.

\section{Conflict of Interests}

The authors declare no conflict of interests.

\section{References}

Addi-Raccah, A., \& Dana, O. (2015). Private tutoring intensity in schools: A comparison between high and low socio-economic schools. International Studies in Sociology of Education, 25(3), 183-203.

Al-Haj, M. (2012). Education, empowerment, and control: The case of the Arabs in Israel. Albany, NY: Suny Press.

Arbel, Y., Bar-El, R., \& Tobol, Y. (2017). Equal opportunity through higher education: Theory and evidence on privilege and ability. Kiel: Leibniz Information Centre for Economics.

$\mathrm{Au}, \mathrm{W}$. (2014). Hiding behind high-stakes testing: Meritocracy, objectivity and inequality in US education. International Education Journal: Comparative Perspectives, 12(2), 7-19.

Ayalon, H. (1990). The social impact of nonregular education in Israel. Comparative Education Review, 34(3), 302-313.

Ayalon, H., \& Shavit, Y. (2004). Educational reforms and inequalities in Israel: The MMI hypothesis revisited. Sociology of Education, 77(2), 103-120.

Ayalon, H., Shapira, R., \& Shavit, R. (1992). A second chance for higher education: Academic preparatory programs in Israel. Research in Higher Education, 33(4), 497-510.

Bar-Haim, E., \& Semyonov, M. (2015). Ethnic stratification in Israel. In The international handbook of the demography of race and ethnicity (pp. 323-337). Dordrecht: Springer.

Bar-Haim, E., \& Shavit, Y. (2013). Expansion and inequality of educational opportunity: A comparative study. Research in Social Stratification and Mobility, 31, 22-31.

Bar-Haim, E., Chauvel, L., Gornick, J., \& Hartung, A. (2018). The persistence of the gender earnings gap:
Cohort trends and the role of education in twelve countries (LIS Working Paper 737). Esch-Belval: CrossNational Data Center in Luxembourg.

Bar-Haim, E., Yaish, M., \& Shavit, Y. (2008). Up the down escalators: Expansion and stratification in education. Israeli Sociology, 10(1), 61-80.

Beller, M. (2001). Admission to higher education in Israel and the role of the psychometric entrance test: Educational and political dilemmas. Assessment in Education: Principles, Policy \& Practice, 8(3), 315-337.

Blank, C. (2008). "Dark handcuff": Inspection of affirmative action program for integration of Ethiopian Jews into police and high education (Unpublished master's thesis). Tel-Aviv: Tel-Aviv University.

Blank, C., \& Shavit, Y. (2016). The association between student reports of classmates' disruptive behavior and student achievement. AERA Open, 2(3). https://doi.org/10.1177/2332858416653921

Blank, C., Shavit, Y., \& Yaish, M. (2016). Tracking and attainment in Israeli secondary education. In H.-P. Blossfeld, J. Skopel, M. Triventi, \& S. Buchholtz (Eds.), Secondary education models and social inequality: An international comparison (pp. 361-377). Cheltenham: Edward Elgar.

Blass, N., \& Shavit, Y. (2017). Israel's education system in recent years: An overview (State of the Nation Report 207). New York, NY: Taub Center.

Buchholz, S., \& Schier, A. (2015). New game, new chance? Social inequalities and upgrading secondary school qualifications in West Germany. European Sociological Review, 31(5), 603-615.

Central Bureau of Statistics. (2013). PUF: Long term household panel, first wave 2012. Jerusalem: Central Bureau of Statistics.

Central Bureau of Statistics. (2014). PUF: Long term household panel, second wave 2013. Jerusalem: Central Bureau of Statistics.

Central Bureau of Statistics. (2016). PUF: Long term household panel, third wave 2014-2015. Jerusalem: Central Bureau of Statistics.

Central Bureau of Statistics. (2017a). PUF: Long term household panel, fourth wave 2016. Jerusalem: Central Bureau of Statistics.

Central Bureau of Statistics. (2017b). PUF: The Israeli Social Survey. Jerusalem: Central Bureau of Statistics.

Chachashvili-Bolotin, S., \& Lissitsa, S. (2016). Enrollment in religious schools and the educational achievements of children of high-skill immigrants. International Migration Review. Advance online publication. https://doi.org/10.1111/imre.12266

Cohen, Y., Haberfeld, Y., \& Kristal, T. (2007). Ethnicity and mixed ethnicity: Educational gaps among Israeli-born Jews. Ethnic and Racial Studies, 30(5), 896-917.

Davidovitch, N., \& Soen, D. (2015). Predicting academic success using admission profiles. Journal of International Education Research, 11(3), 125.

Feniger, Y. (2018). Socioeconomic inequality in Israel: A theoretical and empirical analysis. New York, NY: Pal- 
grave Macmillan.

Feniger, Y., Mcdossi, O., \& Ayalon, H. (2014). Ethnoreligious differences in Israeli higher education: Vertical and horizontal dimensions. European Sociological Review, 31(4), 383-396.

Friedlander, D., Okun, B. S., \& Goldscheider, C. (2016). Ethno-religious hierarchy in educational achievement and socioeconomic status in Israel: A historical perspective. In S. Miaari (Ed.), Socioeconomic inequality in Israel (pp. 97-121). New York, NY: Palgrave Macmillan.

Gale, T. C., \& McNnamee, P. J. (1995). Alternative pathways to traditional destinations: Higher education for disadvantaged Australians. British Journal of Sociology of Education, 16(4), 437-450.

Helms, R. (2015). University admissions: Practices and procedures worldwide. International Higher Education, 54(2015), 5-7.

Inbar, D., \& Sever, R. (1989). The importance of making promises: An analysis of second-chance policies. Comparative Education Review, 33(2), 232-242.

Lewin-Epstein, N., \& Semyonov, M. (1993). The Arab minority in Israel's economy: Patterns of ethnic inequality. Boulder, CO: Westview Pr.

Lucas, S. R. (2001). Effectively maintained inequality: Education transitions, track mobility, and social background effects. American Journal of Sociology, 106(6), 1642-1690.

Lucas, S. R. (2009). Stratification theory, socioeconomic background, and educational attainment: A formal analysis. Rationality and Society, 21(4), 459-511.

Marks, G. N. (2013). Evaluating effectively maintained inequality: School and post-school transitions, socioeconomic background, academic ability and curricular placement. Social Science Research, 42(6), 1635-1649.

Okun, B. S., \& Friedlander, D. (2005). Educational stratification among Arabs and Jews in Israel: Historical disadvantage, discrimination, and opportunity. Population Studies, 59(2), 163-180.

Raffe, D. (1979). The alternative route reconsidered: Parttime further education and social mobility in England and Wales. Sociology, 13(1), 47-73.

Raftery, A. E., \& Hout, M. (1993). Maximally maintained inequality: Expansion, reform, and opportunity in Irish education, 1921-75. Sociology of Education, 66(1), 41-62.
Savelsberg, H., Pignata, S., \& Weckert, P. (2017). Second chance education: Barriers, supports and engagement strategies. Australian Journal of Adult Learning, 57(1), 36.

Schudde, L., \& Goldrick-Rab, S. (2015). On second chances and stratification: How sociologists think about community colleges. Community College Review, 43(1), 27-45.

Shafir, G., \& Peled, Y. (1998). Citizenship and stratification in an ethnic democracy. Ethnic and Racial Studies, 21(3), 408-427.

Shavit, Y. (1984). Tracking and ethnicity in Israeli secondary education. American Sociological Review, 49(2), 210-220.

Shavit, Y. (1990). Segregation, tracking, and the educational attainment of minorities: Arabs and Oriental Jews in Israel. American Sociological Review, 55(1), 115-126.

Shavit, Y., Ayalon, H., \& Kurlaender, M. (2002). Schooling alternatives, inequality, and mobility in Israel. In Schooling and social capital in diverse cultures (pp. 105-124). Bingley: Emerald Group Publishing Limited.

Stier, H., \& Herzberg-Druker, E. (2017). Running ahead or running in place? Educational expansion and gender inequality in the labor market. Social Indicators Research, 130(3), 1187-1206.

The State Comptroller. (2016). The council for higher education: The academic preparatory schools, State of Israel (Ombudsman Annual Report 66c). Retrieved from www.mevaker.gov.il/he/Reports/Report_537/ 057b6941-fe3f-40ef-a026-3103e09063a1/307-mehi not.pdf?AspxAutoDetectCookieSupport=1

Triventi, M., Panichella, N., Ballarino, G., Barone, C., \& Bernardi, F. (2016). Education as a positional good: Implications for social inequalities in educational attainment in Italy. Research in Social Stratification and Mobility, 43, 39-52.

Van Hek, M., Kraaykamp, G., \& Wolbers, M. H. (2016). Comparing the gender gap in educational attainment: The impact of emancipatory contexts in 33 cohorts across 33 countries. Educational Research and Evaluation, 22(5/6), 260-282.

Zilkha, G. (2017). Innovative higher education learning outcomes and financing trends in Israel. International Journal of Educational Development, 58(C), 128-136.

\section{About the Authors}

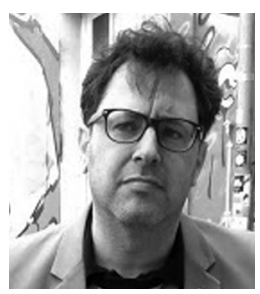

Eyal Bar-Haim is a Post-Doctoral Researcher at the PEARL Institute for Research of Socio-Economic Inequalities (IRSEI) at the University of Luxembourg. He obtained his PhD from the University of Tel-Aviv (Israel). He is mainly interested in the analysis of mobility, stratification, inequality of opportunities and economic inequality. He published several journal articles and book chapters on inequality of opportunities in Israel and in a comparative, international perspective. 
Carmel Blank, PhD, is a Postdoctoral Research Associate in the School of Applied Social Sciences at Durham University, in England, and lecturer in the Department of Sociology and Anthropology in Tel Aviv University. She is also an Education Policy Program Fellow at the Taub Centre for Social Policy Studies in Israel. Her research interests are social stratification and educational inequality with a focus on classroom disciplinary climate. She has worked in various international comparative projects and published several articles as well as book chapters. 